PRODUCTION

ENGINEERING ARCHIVES
2015, Vol. 8, No 3, pp 32-35

ISSN 2353-5156 (print version)

ISSN 2353-7779 (online version)

\title{
Factors describing the concept of plastics company development
}

\author{
Krzysztof Mielczarek ${ }^{1}$ \\ ${ }^{1}$ Institute of Production Engineering, Faculty of Management, Czestochowa University of Technology, Armii Krajowej 19B, \\ 42-201 Czestochowa, Poland, e-mail: mielczarek@zim.pcz.pl
}

Abstract. In the article enterprise producing different type of plastics was presented. A production process of one product was presented. Results of the BOST survey were introduced. A statistical analysis in the range of the principle 1 of Toyota was undertaken. A structure of evaluations was determined and correlation graphs presenting relations between factors and respondents' features were built.

Key words - BOST, principles of the Toyota, improvement, production process

\section{Introduction}

The enterprise is dealing with the production of flowerpots from plastic, ceramics and artistic metalwork. At present such products are produced: balcony boxes, terrace boxes, terrace flowerpots, garden fences, lawns, stands, candlesticks, flower beds, ceramic flowerpots and ceramic shields. In Fig. 1 the production process of the flowerpot in technological aspect is presented.

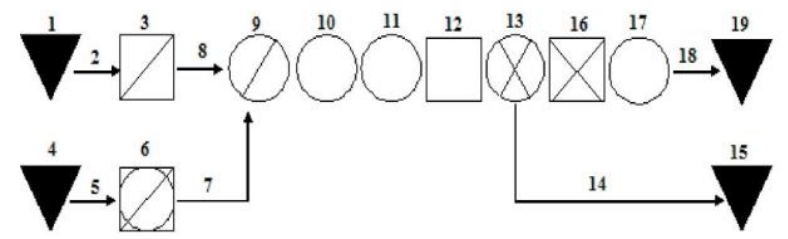

Fig. 1. Production process of the flowerpot in the technological aspect.

Source: own study.

Individual symbols in a production process mean: 1 . Storage of raw materials. 2. Transport - 1min. 3. The preliminary control of pellets - $1 \mathrm{~min}$. 4. Storage of raw materials. 5. Transporting of dyes to the factory floor 1 min. 6. Real processing, rotational mixing up in the round barrel together with appropriate dye -30min. 7.8. Transport - $1 \mathrm{~min}$. 9. Pre-treatment, heating the polypropylene to $50^{\circ} \mathrm{C}-75^{\circ} \mathrm{C}-15 \mathrm{~min}$. 10 . Real processing $0.5 \mathrm{~min}$. 11. Real processing, hardening of the polypropylene in the form $-0.5 \mathrm{~min}$. 12 . The visual control, testing the parameters of the casting - $1 \mathrm{~min}$. 13. After-machining, cutting or grinding ensuing casts during the process of the injection - $2 \mathrm{~min}$. 14. Transport of the industrial waste of all kinds (clippings, sinks) - 4min. 15. Storage. 16. The final control, checking the smoothness of the surface - 1min. 17. Packing flowerpots into plastic sleeves and laying them on the palette $-15 \mathrm{~min} .18$. Transport of finished products on the palette to the magazine - 2min. 19. Storage of finished products.

\section{Methodology of research and presen- tation of results}


Valuable complement of carried out research there is interpretation of BOST questionnaire results (BORKOWSKI S., KNOP K., BARTCZAK M. 2011). It gives a better look at the enterprise through the eyes of workers. In the purpose to form an opinion it is essential to know the opinion of workers from different ranks in the enterprise (BORKOWSKI S. 2012a). BOST is a survey where the questions are so well-matched to judge enterprise and its immaterial stores are possible (KRYNKE M., JAGUSIAK-KOCIK M. 2014). Results were placed in tables that allowed an analysis. In order to the identify the factors that decide on the conception of the enterprise development, 30 people filled a BOST questionnaire (BORKOWSKI S. 2012b). The person who is filling in the questionnaire is judging factors:

- customer's interest (DK),

- product innovation (IP)

- cooperation with partners (WK),

- confidence in relations with employees (ZP),

- independence and responsibility of employees $(S P)$,

- development of technology (RT),

- company culture care (PR).

They judged 7 factors using a scale from 1 to 7 , where 1 means the least essential element, and 7 - the most important element. (BORKOWSKI S. 2012c).

Table 1. Numerical evaluation structure of the factors importance

\begin{tabular}{|c|c|c|c|c|c|c|c|}
\hline \multirow{2}{*}{$\begin{array}{l}\text { Eva- } \\
\text { lua- } \\
\text { tion }\end{array}$} & \multicolumn{7}{|c|}{ Indicating the factors } \\
\hline & DK & IP & WK & ZP & SP & RT & PR \\
\hline 1 & $\boldsymbol{0}$ & $\boldsymbol{0}$ & 1 & 7 & 15 & 7 & $\boldsymbol{0}$ \\
\hline 2 & $\boldsymbol{0}$ & 1 & $\boldsymbol{0}$ & 14 & 10 & 3 & 2 \\
\hline 3 & 3 & 4 & 4 & 3 & 3 & 10 & 3 \\
\hline 4 & 3 & 3 & 7 & 5 & 0 & 2 & 10 \\
\hline 5 & 2 & 6 & 12 & 1 & 2 & 2 & 5 \\
\hline 6 & 4 & 10 & 4 & $\boldsymbol{0}$ & 0 & 3 & 9 \\
\hline 7 & 18 & 6 & 2 & $\boldsymbol{0}$ & $\boldsymbol{0}$ & 3 & 1 \\
\hline
\end{tabular}

Source: own study.

\section{Statistical analysys}

Making statistical analysis of a studied area six statistical tools were used: arithmetic average, variance, standard deviation, the coefficient of variation, skewness and excess coefficient (Fig. 2).
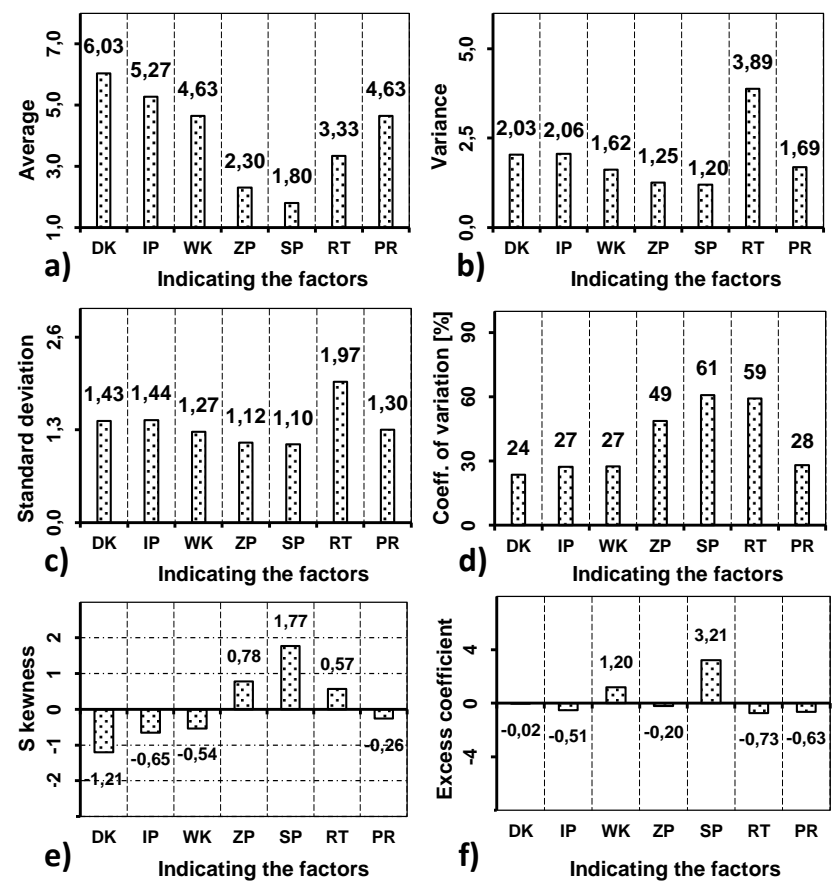

Fig. 2. Comparison: a) averages, b) standard deviation, c) variance, d) coefficient of variation, $e$ ) skewness, $f$ ) excess Source: own study coefficient for E2 area factors.

The average level of measurable features in statistical form was presented (Fig. 2a). The graph showing that the greatest average value has the customer's good (DK) and is taking out 6.03. The next statistical tool is a variance (PUŁASKA-TURYN B. 2008) that is essential for interpretation of the BOST survey. From Fig. $2 \mathrm{~b}$ results that the maximum value of variance 3.89 received development of the technology (RT). For the standard deviation (Fig. 2c) the maximum value is presenting the same as for the variance development of the technology (RT) 1.97. The next statistical tool determining the area of the changeability is a coefficient of variation (Fig. 2d). The biggest diversity is observed for the factor independence and the responsibility of workers (SP) at $61 \%$. Skewness (Fig. 2e) is the simplest measure of the asymmetry of the distribution. After analysing results four factors have negative values and three factors demonstrate positive values. The highest value reached independence and the responsibility of workers (SP) equals 1.77. The last graph introducing excess coefficient (Fig. 2f) shows that the closest normal distribution is the factor the customer's good (DK). 


\section{Building importance series for ana- lyzed factors}

For the individual evaluations of factors Pareto-Lorenz diagrams were constructed. It was taken in terms of the assessment considering value allotted to determined factors (BORKOWSKI S., ULEWICZ R. 2009). On the basis of Table 1 the structure of assessments was made (Fig. 3). Seven diagrams were presented where each one shows the distribution of factors based on the importance for the researched area. Each diagram presents an accumulated value of individual assessments from „" to „7” (SYGUT P. 2014).
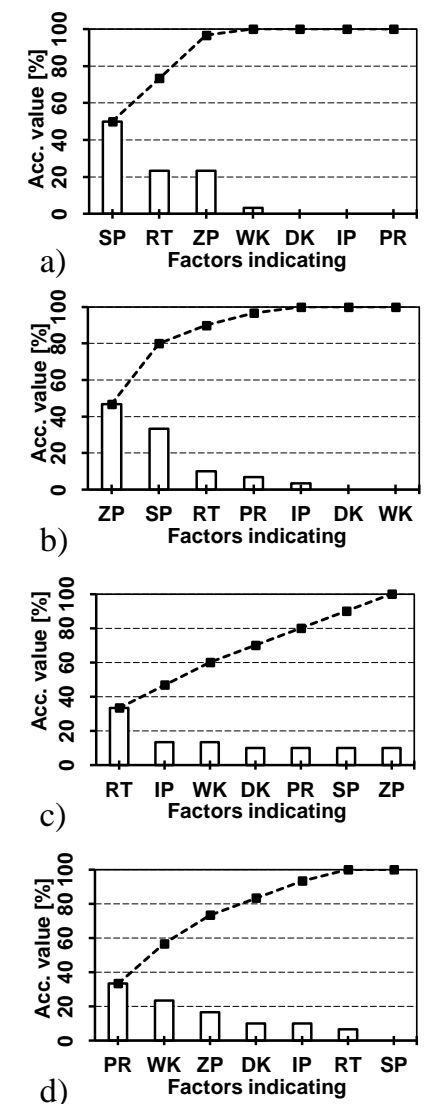

d)

Factors indicating
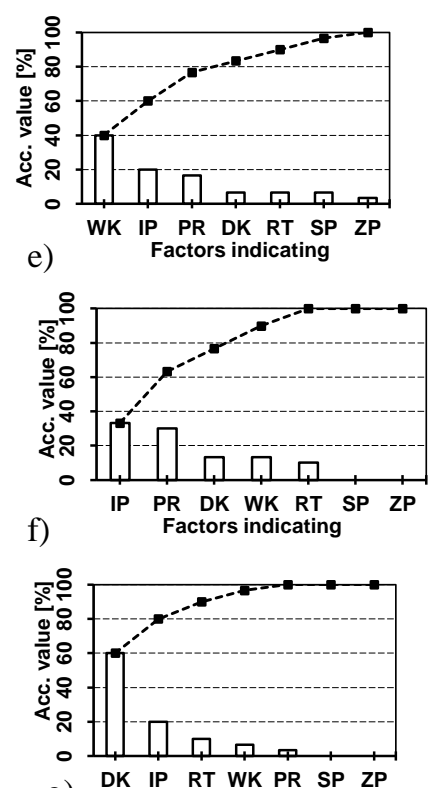

g) DK IP RT WK PR SP

Fig. 3. Pareto-Lorenz diagrams of the factors' importance E2 area for evaluations: a) ,, 1 ," b) ,2," c) ,,3”, d) ,4,", e) ,, 5 ", f) ,, 6", g),, 7 ".

On the basis of Fig. 3 an important series of factors for evaluation, $1 \div 7$ " were presented. Formula 1 shows an importance series of factors for evaluation , 1 ”. On the basis of received results it was found that the highest evaluation "1" received was independence and responsibility of employees (SP).

$$
\mathrm{SP}>\mathrm{RT}>\mathrm{ZP}>\mathrm{WK}>\mathrm{DK}>\mathrm{IP}>\mathrm{PR}
$$

Fig. $3 \mathrm{f}$ and formula 2 shows an importance series of factors for the highest evaluation „7". The highest evaluation , "7" received a factor product innovation (IP).

$$
\mathrm{IP}>\mathrm{PR}>\mathrm{DK}>\mathrm{WK}>\mathrm{RT}>\mathrm{SP}>\mathrm{ZP}
$$

Fig. $3 \mathrm{~g}$ and formula 3 shows an importance series for the average.

$$
\mathrm{DK}>\mathrm{IP}>\mathrm{RT}>\mathrm{WK}>\mathrm{PR}>\mathrm{SP}>\mathrm{ZP}
$$

The factor customer's interest (DK) is the area which was regarded as the most important and the factor confidence in relations with employees $(\mathrm{ZP})$ was recognised as the least essential.

\section{Correlation analysis and summary}

For the purpose of a wider statistical analysis of respondent's replies a correlation analysis was carried out. The main purpose of interpreting correlation graphs is finding out whether there is any correlation between provided answer and respondent's feature (KRYNKE M., 
KONOP K., MiELCZAREK K. 2014). An importance of correlation for three $\alpha$ level: $\alpha=0.2, \alpha=0.1$ and $\alpha=$ 0.05. Fig. 4 presented correlation graphs of factors depending on respondent's features. The first graph shows a correlation between respondent's gender and significance rates for factors describing the first Toyota's management principle. It can be noted that statistically only in the case of one element a significant correlation has occurred for factor development of technology (RT) on one $\alpha$ level. The education of workers influence in strategic areas on three $\alpha$ level for the factors development of technology (RT) - strong negative correlation. For factor independence and responsibility of employees (SP) there is a positive correlation on two $\alpha$ level.

Age of respondents, have the most significant influence on factors cooperation with partners (WK) strong negative correlation. Work experience demonstrates a correlation on every $\alpha$ level for factor cooperation with partners (WK) but also a strong negative correlation. In the case of the mobility, correlation is negative for the factors cooperation with partners (WK) and positive for factors confidence in relations with employees (ZP) and independence and responsibility of employees (SP). In the case of the method of recruitment, the correlation is negative for factors cooperation with partners (WK).
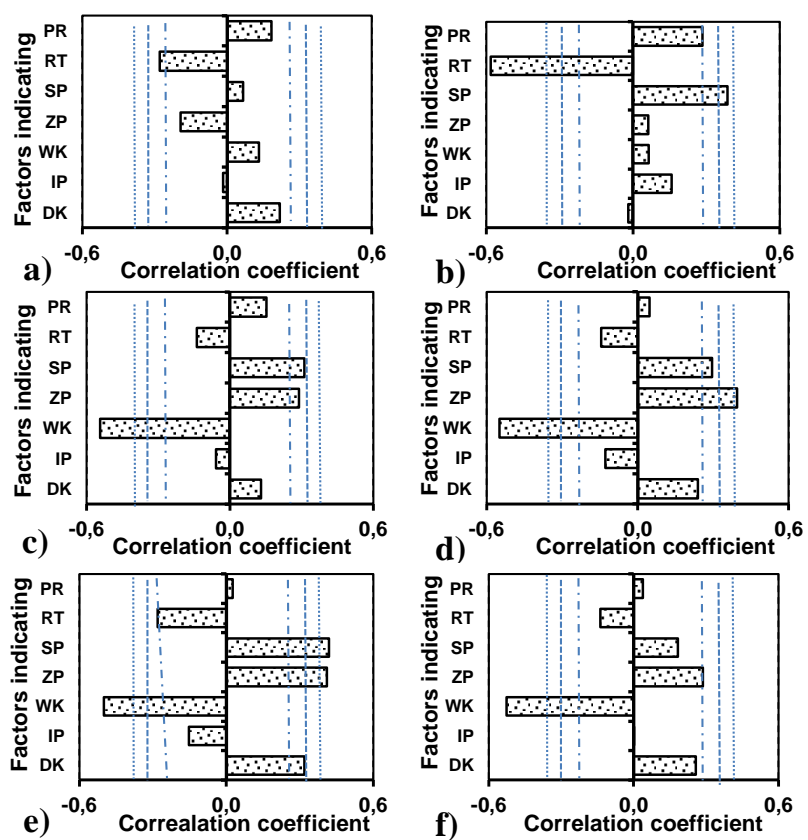

Fig. 4. Correlation graphs for factors in E2 area depending on the respondents' features: a) gender, b) education, c) age, d) work experience, e) mobility, f) way of recruitment $\alpha=0,2$ (internal lines), $\alpha=0,1$ (central lines), $\alpha=0,05$ (external lines).

Source: own study

The age of respondents has an essential influence on the factor cooperation with partners (WK) - a strong negative correlation. Work experience demonstrates a correlation on every $\alpha$ level for factor cooperation with partners (WK) and also a strong negative correlation. In the case of the mobility, correlation is negative for factors cooperation with partners (WK) and positive for factors confidence in relations with employees $(\mathrm{ZP})$ and independence and responsibility of employees (SP). In the case of the method of recruitment, the correlation is negative for factors cooperation with partners (WK).

The structure of human resources in the researched enterprise is the following: the majority there are women, the staff is about the diversified level of education (20\% primary, $3 \%$ vocational school, $47 \%$ secondary education, $30 \%$ higher education). As regards the age they are mainly young people (40\% 30-40 years), work experience - the most from 5 to 10 years. For $47 \%$ of respondents this work place is the first place of employment. In the opinion of the staff the most important factor deciding the conception of the development of the enterprise is the customer's good (DK) because $60 \%$ respondents granted this factor the highest evaluation "7". The smallest influence was deemed to be the factor confidence in relations with employees (ZP).

\section{References}

1. BORKOWSKI S. 2012a. Dokumenty zawierajace wymyślony termin (TOYOTARYZM) oraz zawierajace nazwę $i$ strukture opracowanej metody (BOST). Potwierdzenie daty. „AAK” KANCELARIA PATENTOWA s.c. Częstochowa.

2. BORKOWSKI S. 2012b. Zasady zarzadzania Toyoty w pytaniach. Wyniki badań BOST. Wydawnictwo PTM. Warszawa.

3. BORKOWSKI S. 2012c. Toyotaryzm. Wyniki badań BOST. Wydawnictwo PTM. Warszawa.

4. PUŁASKA-TURYN B. 2008. Statystyka dla ekonomistów. Wydanie II rozszerzone. Difin. Warszawa.

5. BORKOWSKI S., KNOP K., BARTCZAK M. 2011. The importance of production factors during manufacturing of rubber products. Chapter 8. [In]: Toyotariy. Production factors. BORKOWSKI S., SYGUT P. (ed.). Publisher Yurii V. Makovetsky. Dnipropetrovsk. 
6. BORKOWSKI S., ULEWICZ R. 2009. Zarzadzanie produkcja. Systemy produkcyjne. Wydawnictwo „HUMANITAS”. Sosnowiec.

7. KRYnKe M., JagusiaK-KociK M. 2014. Czynniki decydujace o koncepcji rozwoju w przedsiębiorstwie produkujacym kotty centralnego ogrzewania. Rozdziat 10. [In]: BorkOwSKI S., SYGUT P. (ed). Toyotaryzm. Znaczenie innowacji w metodzie BOST. Oficyna Wydawnicza Stowarzyszenia Menedżerów Jakości i Produkcji. Częstochowa.

8. KRYNKE M., KONOP K., MIELCZAREK K. 2014. Identifying variables that influence manufacturing product quality. Production Engineering Archives. Vol. 4(3)/2014. s.

9. LIKER J.K. 2005. Droga Toyoty. 14 zasad zarzadzania wiodacej firmy produkcyjnej świata. Wydawnictwo MT Biznes. Warszawa.

10. SYGUT P. 2014. Wykorzystanie czynników zasady 1 zarzadzania Toyoty do oceny procesu malowania proszkowego. Rozdziat 8. [In]: Borkowski S., Sygut P. (red). Toyotaryzm. Znaczenie innowacji $w$ metodzie BOST. Oficyna Wydawnicza Stowarzyszenia Menedżerów Jakości i Produkcji. Częstochowa. 